\title{
Pelatihan Membuat Karya Seni Mozaik untuk Meningkatkan Sikap Sosial Siswa Tunagrahita Kelas V SLB Negeri 2 Buleleng
}

\author{
Heni Adawiyah $^{1}$, I Putu Agus Adi Saputra ${ }^{2}$, Ni Kadek Noviana Sastra Dewi ${ }^{3}$, \\ Kadek Suranata ${ }^{4}$ \\ heni.adawiyah02@gmail.com ${ }^{1}$, adisaputraaa52@gmail.com², \\ novianasastradewi55@gmail.com ${ }^{3}$,kadek.suranata@undiksha.ac.id ${ }^{4}$ \\ PGSD, FIP, Universitas Pendidikan Ganesha ${ }^{1234}$
}

\begin{abstract}
Abstrak: Penelitian ini bertujuan untuk mengetahui sikap sosial dalam mengikuti kegiatan membuat karya seni mozaik pada siswa tunagrahita kelas V di SLB Negeri 2 Buleleng. Penelitian ini merupakan penelitian kuantitatif yang mendeskripsikan mengenai sikap sosial siswa tunagrahita dalam mengikuti kegiatan pembuatan karya seni mozaik. Populasi dalam penelitian ini adalah siswa kelas V di SLB Negeri 2 Buleleng. Sampel yang diambil pada penelitian ini sebanyak 7 peserta didik yang terdiri dari tunagrahita ringan dan sedang. Metode pengumpulan data dalam penelitian ini menggunakan metode observasi, wawancara dan dokumentasi. Hasil penelitian ini menunjukkan peningkatan sikap sosial siswa yang dilihat dari rata-rata skor awal yang diperoleh 37,1 dan setelah dilaksanakan pelatihan kegiatan membuat karya seni mozaik secara berkelompok menunjukkan rata-rata 87,1.
\end{abstract}

Kata Kunci: Tunagrahita, sikap sosial, karya seni mozaik

\section{Training on Making Mosaic Artwork to Improve the Social Attitude of Students Mental Retardation Fifth Grade of SLB Negeri 2 Buleleng}

\begin{abstract}
This study aims to determine the social attitudes in participating in making mosaic artworks for fifth grade mental retardation students in SLB Negeri 2 Buleleng. This research is a quantitative research that describes the social attitudes of mentally retarded students in participating in the making of mosaic artwork. The population in this study were fifth grade students at SLB Negeri 2 Buleleng. The samples taken in this study were 7 students consisting of mild and moderate mental retardation. The method of data collection in this study using the method of observation, interviews and documentation. The results of this study indicate an increase in students' social attitudes seen from the average initial score obtained 37.1 and after training in making activities of mosaic arts in groups showed an average of 87.1.
\end{abstract}

Keywords: mental retardation, social attitudes, mosaic artwork 
Heni, Agus, Noviana, Suranata. Pelatihan Membuat Karya Seni....

PENDAHULUAN

Pendidikan merupakan salah satu upaya untuk memanusiakan manusia melalui pengajaran maupun pelatihan. Dalam UU No. 20 Tahun 2003 menjelaskan pendidikan adalah usaha sadar dan terencana untuk mewujudkan suasana belajar dan proses pembelajaran agar peserta didik secara aktif mengembangkan potensi dirinya untuk memiliki kekuatan spiritual keagamaan, pengendalian diri, kepribadian, kecerdasan, akhlak mulia, serta keterampilan yang diperlukan dirinya, masyarakat, bangsa dan negara.

Pendidikan memiliki peranan yang penting bagi suatu bangsa karena pendidikan dapat dijadikan sebagai salah satu tolak ukur kemajuan suatu negara. Pendidikan pada dasarnya dapat diikuti oleh semua kalangan individu, tak terkecuali bagi individu yang memiliki kebutuhan khusus. Dalam upaya pemerataan pendidikan untuk semua kalangan, anak yang memiliki kebutuhan khusus juga dapat mengenyam pendidikan layaknya anak normal pada umumnya.

Salah satunya jenis anak berkebutuhan khusus yaitu anak tunagrahita (mental retardation). Juriana (2016) menyatakan tunagrahira merupakan istilah yang sering digunakan untuk mereka yang mengalami gangguan intelektual atau keterbelakangan mental antara lain: lemah pikiran, anak lamban, bodoh, dungu, terbelakang, dan sebagainya. Tunagrahita merupakan kata lain dari retardasi mental yang berarti keterbelakangan secara mental. Hal senada juga disampaikan oleh Soemantri (dalam Yusuf, 2017:7) yang menyatakan bahwa tunagrahita adalah istilah yang digunakan untuk menyebut anak yang mempunyai kemampuan intelektual dibawah rata-rata. Istilah tersebut sesungguhnya memiliki arti yang sama yang menjelaskan kondisi anak yang kecerdasannya jauh dibawah rata-rata dan ditandai oleh keterbatasan inteligensi dan ketidakcakapan dalam interaksi sosial.

Selain memiliki keterbatasan dalam tingkat intelegensi, anak tunagrahita juga memiliki ketidakcakapan dalam interaksi sosialnya. Seperti yang dijelaskan oleh Juriana (2018) karakteristik sosial emosi anak tunagrahita pada umumnya yaitu: a) Lamban dalam mempelajari hal-hal baru, b) Mempunyai kesulitan dalam mempelajari pengetahuan abstrak, selalu cepat lupa apa yang dipelajari jika tanpa latihan yang terus menerus, c) Mengalami kesulitan dan menggeneralisasikan dan mempelajari hal-hal baru, d) Kemampuan berbicara sangat kurang terutama tunagrahita sedang/berat, e) 
Heni, Agus, Noviana, Suranata. Pelatihan Membuat Karya Seni...

Kurang dalam kemampuan menolong diri sendiri, sebagian tidak mampu mengurus diri sendiri seperti: berpakaian, makan, menjaga kebersihan, sehingga diperlukan latihan khusus untuk memiliki kemampuan ini dan f) Mengalami kesulitan dalam berinteraksi.

Dalam mengajarkan siswa tunagrahita tidak hanya menekankan pada aspek kognitifnya, namun juga harus memperhatikan aspek afektif siswa salah satunya adalah sikap sosial. Sikap sosial siswa dalam proses pembelajaran harus diperhatikan karena sikap siswa dapat mempengaruhi interaksi yang terjalin dalam proses pembelajaran. Sudarsono (dalam Prasetya, 2018:14) mendefinisikan social attitudes (sikap sosial) yaitu sebagai perbuatan-perbuatan atau sikap yang tegas dari seseorang atau kelompok didalam keluarga atau masyarakat. Sikap sosial siswa untuk tungrahita berkiatan dengan penentuan tingkah laku terhadap orang lain dengan mementingkan tujuan sosial dibandingkan kepentingan individu dalam lingkungan sosial.

Proses pembelajaran yang baik, tentunya harus melibatkan interaksi antara siswaguru, siswa-siswa dan guru-siswa. Dalam mengembangkan sikap sosial anak, interkasi antara siswa-siswa sangat penting untuk ditekankan. Namun, dalam kenyataanya, proses interaksi antar siswa-siswa pada siswa tunagrahita tidak berlangsung dengan baik. Ketidakcakapan anak tunagrahita dalam melaksanakan interaksi sosial dapat dilihat dari sikap anak yang hiperaktif dan ada juga anak yang pasif. Hal tersebut mengakibatkan interaksi yang terjalin antar anak akan sulit dikembangkan. Selain itu, anak juga cenderung tidak mau untuk bekerja secara kelompok. Mereka tidak mau bekerjasama dan berdiskusi untuk menyelesaikan sebuah tugas maupun permasalahan. Hal itu yang menyebabkan sikap sosial anak tunagrahita tidak dapat berkembang secara optimal.

Sehubungan dengan hal tersebut, peneliti memilih untuk meningkatkan sikap sosial anak tunagrahita yang dilakukan melalui kegiatan pembelajaran secara berkelompok. Kegiatan pembelajaran yang dilaksanakan merupakan kegiatan yang termasuk ke dalam proses belajar sambil bermain guna menarik minat anak. Salah satu kegiatan pembelajaran yang dapat dilakukan untuk menumbuhkan sikap sosial anak tunagrahita yaitu mengajak anak untuk membuat karya seni, salah satunya adalah mozaik. Menurut Yustiana (2018) mozaik adalah suatu cara membuat kreasi gambar/lukisan yang dilakukan dengan cara menempelkan/ merekatkan potongan-potongan atau bagian-bagian bahan tertentu yang ukurannya kecil-kecil. Dari pengertian tersebut, dapat diartikan bahwa dalam 
Heni, Agus, Noviana, Suranata. Pelatihan Membuat Karya Seni.... penerapannya, mozaik hanya menggunakan satu bahan saja. Bahan-bahan yang dapat digunakan yaitu biji-bijian, kertas berwarna, daun-daunan, kaca berwarna dan lain-lain.

Kelebihan karya seni mozaik ini didukung oleh penelitian yang dilakukan oleh Dwi (2018) berjudul "Penerapan Media Mozaik Dalam Meningkatkan Keterampilan Mengenakan Pakaian Berkancing Pada Anak Tunagrahita Sedang” yang menyatakan bahwa mozaik dapat meningkatkan keterampilan mengenakan pakaian berkancing pada anak tunagrahita sedang. Selain itu, mozaik dianggap sebagai media yang mampu menunjang kebutuhan belajar siswa dalam hal melatih kemampuan fisik tangan, latihan konsentrasi, dan latihan koordinasi tangan-mata.

Berdasarkan hasil wawancara dengan wali kelas V di SLB Negeri 2 Buleleng diperoleh guru belum menerapkan pembelajaran secara berkelompok dikarenakan siswa tunagrahita memiliki tingkat ego yang tinggi. Siswa cenderung kurang berinteraksi dengan baik dengan temannya. Selain itu, apabila dikelola secara berkelompok siswa merasa kurang nyaman dengan teman kelompoknya dan sering memperebutkan sesuatu untuk kepentingan dirinya sendiri. Penggunaan media mozaik yang dilakukan secara berkelompok memungkinkan siswa untuk belajar berinteraksi dan bekerja sama dengan teman kelomponya.

Adapun langkah-langkah yang akan dilakukan untuk mengajarkan anak membuat karya seni mozaik yaitu: 1) menumbuhkan minat anak dengan memberikan contoh karya seni mozaik. Contoh karya seni mozaik yang dapat diberikan berupa contoh mozaik tentang buah-buahan maupun bunga, 2) memperkenalkan bahan-bahan yang digunakan dalam kegiatan membuat mozaik. Bahan-bahan yang dapat digunakan yaitu potongan-potongan kecil kertas warna-warni, lem serta sketsa gambar buahbuahan atau bunga, 3) membentuk anak menjadi beberapa kelompok yang terdiri dari 2 orang, 4) membagikan bahan-bahan yang akan digunakan untuk membuat karya seni mozaik kepada masing-masing anak, dan 5) meminta anak untuk mengambil potonganpotongan kertas yang telah tersedia.

\section{METODE}

Jenis penelitian adalah penelitian deskriptif dengan tujuan mendeskripsikan sikap sosial anak tunagrahita kelas V di SLB Negeri 2 Buleleng sebelum menerapkan pelatihan membuat karya seni mozaik. Penelitian ini menggunakan metode kuantitatif dengan teknik 
Heni, Agus, Noviana, Suranata. Pelatihan Membuat Karya Seni... analisis kuantitatif yang dipergunakan pada hasil data wawancara, observasi dan dokumentasi. Jenis penelitian digunakan untuk menggambarkan sikap sosial siswa dengan pengukuran lima indikator sikap sosial. Penelitian dilakukan pada bulan April 2019 di SLB Negeri 2 Buleleng. Subjek penelitian adalah siswa kelas V SLB Negeri 2 Buleleng Tahun Pelajaran 2018/2019 yang berjumlah 7 orang. Dalam penelitian ini, subjek yang diteliti hanya siswa tunagrahita yang tergolong rendah dan sedang. Peningkatan sikap sosial siswa dapat diketahui dari pelaksanaan kegiatan membuat karya seni mozaik yang disesuaikan dengan indikator yang diadaptasi dari Lestari (2015).

\section{HASIL}

Tahapan awal dari penelitian ini adalah penyusunan indikator penilaian yang diadaptasi dari Lestari (2015). Adapun gambaran umum atau kategori sikap sosial siswa tunagrahita dalam mengikuti pelatihan membuat karya seni mozaik yaitu seperti Tabel 1.

Tabel 1. Indikator Penilaian Sikap Sosial

\begin{tabular}{|c|c|c|c|}
\hline No & Aspek yang diamati & Skor & Kriteria \\
\hline \multirow{4}{*}{1} & \multirow{4}{*}{ Tindakan siswa menanggapi orang lain } & 4 & Siswa menanggapi pendapat orang lain baik \\
\hline & & 3 & $\begin{array}{l}\text { Siswa menanggapi pendapat orang lain } \\
\text { cukup baik }\end{array}$ \\
\hline & & 2 & $\begin{array}{l}\text { Siswa dapat menanggapi pendapat orang } \\
\text { lain dengan kurang baik. }\end{array}$ \\
\hline & & 1 & $\begin{array}{c}\text { Siswa dapat menanggapi pendapat orang } \\
\text { lain dengan tidak baik. }\end{array}$ \\
\hline \multirow{4}{*}{2} & \multirow{4}{*}{$\begin{array}{l}\text { Sikap siswa mementingkan tujuan-tujuan } \\
\text { sosial daripada tujuan pribadi. }\end{array}$} & 4 & $\begin{array}{c}\text { Siswa sering menunjukkan sikap siswa } \\
\text { mementingkan tujuan-tujuan sosial daripada } \\
\text { tujuan pribadi }\end{array}$ \\
\hline & & 3 & $\begin{array}{l}\text { Siswa kadang-kadang menunjukkan sikap } \\
\text { siswa mementingkan tujuan-tujuan sosial } \\
\text { daripada tujuan pribadi. }\end{array}$ \\
\hline & & 2 & $\begin{array}{l}\text { Siswa jarang menunjukkan sikap siswa } \\
\text { mementingkan tujuan-tujuan sosial daripada } \\
\text { tujuan pribadi. }\end{array}$ \\
\hline & & 1 & $\begin{array}{c}\text { Siswa tidak pernah menunjukkan sikap } \\
\text { siswa mementingkan tujuan-tujuan sosial } \\
\text { daripada tujuan pribadi. }\end{array}$ \\
\hline \multirow{4}{*}{3} & \multirow{4}{*}{ Berperilaku sesuai dengan tuntunan sosial. } & 4 & $\begin{array}{l}\text { Siswa berperilaku sesuai dengan tuntunan } \\
\text { sosial dengan baik. }\end{array}$ \\
\hline & & 3 & $\begin{array}{l}\text { Siswa berperilaku sesuai dengan tuntunan } \\
\text { sosial dengan cukup baik. }\end{array}$ \\
\hline & & 2 & $\begin{array}{l}\text { Siswa berperilaku sesuai dengan tuntunan } \\
\text { sosial dengan kurang baik. }\end{array}$ \\
\hline & & 1 & $\begin{array}{l}\text { Siswa tidak berperilaku sesuai dengan } \\
\text { tuntunan sosial. }\end{array}$ \\
\hline \multirow[t]{2}{*}{4} & \multirow[t]{2}{*}{ Diterima sebagai anggota kelompok sosial. } & 4 & $\begin{array}{l}\text { Siswa diterima sebagai anggota kelompok } \\
\text { sosial dengan baik. }\end{array}$ \\
\hline & & 3 & Siswa diterima sebagai anggota kelompok \\
\hline
\end{tabular}


Heni, Agus, Noviana, Suranata. Pelatihan Membuat Karya Seni....

\begin{tabular}{|c|c|c|c|}
\hline \multirow{2}{*}{} & & & sosial dengan cukup baik \\
\cline { 3 - 4 } & 2 & $\begin{array}{c}\text { Siswa diterima sebagai anggota kelompok } \\
\text { sosial dengan kurang baik. }\end{array}$ \\
\cline { 3 - 4 } & & 1 & $\begin{array}{c}\text { Siswa tidak diterima sebagai anggota } \\
\text { kelompok sosial. }\end{array}$ \\
\hline \multirow{3}{*}{5} & \multirow{3}{*}{ Menyukai aktivitas sosial } & 4 & Siswa menyukai aktivitas sosial. \\
\cline { 3 - 4 } & & 3 & Siswa cukup menyukai aktivitas sosial. \\
\cline { 3 - 4 } & 2 & Siswa kurang menyukai aktivitas sosial. \\
\cline { 3 - 4 } & & 1 & Siswa tidak menyukai aktivitas sosial. \\
\hline
\end{tabular}

(Sumber: Modifikasi dari Lestari, 2015)

Untuk selanjutnya, nilai dihitung melalui persentase dengan menggunakan pedoman penskoran:

Nilai: $=\frac{\text { Jumlah skor yang diperoleh }}{\text { Jumlah skor maksimal }} \times 100$

Setelah diperoleh nilai, kemudian nilai tersebut dimasukkan dalam rentangan hubungan antara skala dengan skala yang mengacu pada pendapat Arikunto (2010)

Tabel 2. Hubungan antara Skala Angka dan Skala Huruf

\begin{tabular}{|c|c|c|}
\hline Rentangan Angka & Huruf & Keterangan \\
\hline $80-100$ & A & Sangat Baik \\
\hline $70-79$ & B & Baik \\
\hline $60-69$ & C & Cukup Baik \\
\hline $50-59$ & D & Kurang Baik \\
\hline $0-49$ & E & Tidak Baik \\
\hline
\end{tabular}

(Sumber: Arikunto, 2010)

Berikut data tentang sikap sosial awal siswa tunagrahita kelas V sebelum dilaksanakan pelatihan membuat karya seni mozaik di SLB Negeri 2 Buleleng sebagai berikut.

Tabel 3. Nilai Awal Sikap Sosial Siswa Tunagrahita Kelas V

SLB Negeri 2 Buleleng

\begin{tabular}{|c|c|c|c|c|c|c|c|c|}
\hline \multirow{2}{*}{ No } & \multirow{2}{*}{ Nama Siswa } & \multicolumn{5}{|c|}{ Indikator Sikap Sosial } & \multirow{2}{*}{ Skor } & \multirow{2}{*}{ Nilai } \\
\hline & & 1 & 2 & 3 & 4 & 5 & & \\
\hline 1 & Ida Ayu Intan Parmitasari & 1 & 2 & 2 & 1 & 2 & 8 & 40 \\
\hline 2 & Gede Dimas & 2 & 1 & 2 & 1 & 2 & 8 & 40 \\
\hline 3 & Komang Tri Satya Guna & 2 & 2 & 2 & 1 & 2 & 9 & 45 \\
\hline 4 & Gede Sukaja Kori & 1 & 1 & 2 & 1 & 1 & 6 & 30 \\
\hline 5 & Made Angga Dwipayana & 1 & 1 & 1 & 1 & 1 & 5 & 25 \\
\hline 6 & Komang Sudartawan & 2 & 2 & 2 & 1 & 2 & 9 & 45 \\
\hline 7 & Komang Suardita & 2 & 1 & 2 & 1 & 1 & 7 & 35 \\
\hline \multicolumn{8}{|c|}{ Jumlah } & 260 \\
\hline \multicolumn{8}{|c|}{ Rata-rata } & 37,1 \\
\hline
\end{tabular}


Heni, Agus, Noviana, Suranata. Pelatihan Membuat Karya Seni....

Tabel 4. Nilai Sikap Sosial Siswa Tunagrahita Kelas V

SLB Negeri 2 Buleleng Selama Mengikuti Kegiatan Membuat Karya Seni Mozaik

\begin{tabular}{|c|c|c|c|c|c|c|c|c|}
\hline \multirow{2}{*}{ No } & \multirow{2}{*}{ Nama Siswa } & \multicolumn{5}{|c|}{ Indikator Sikap Sosial } & \multirow{2}{*}{ Skor } & \multirow{2}{*}{ Nilai } \\
\hline & & 1 & 2 & 3 & 4 & 5 & & \\
\hline 1 & Ida Ayu Intan Parmitasari & 3 & 4 & 4 & 3 & 4 & 18 & 90 \\
\hline 2 & Gede Dimas & 4 & 3 & 4 & 3 & 4 & 18 & 90 \\
\hline 3 & Komang Tri Satya Guna & 4 & 4 & 4 & 3 & 4 & 19 & 95 \\
\hline 4 & Gede Sukaja Kori & 3 & 3 & 4 & 3 & 3 & 16 & 80 \\
\hline 5 & Made Angga Dwipayana & 3 & 3 & 3 & 3 & 3 & 15 & 75 \\
\hline 6 & Komang Sudartawan & 4 & 4 & 4 & 3 & 4 & 19 & 95 \\
\hline 7 & Komang Suardita & 4 & 3 & 4 & 3 & 3 & 17 & 85 \\
\hline \multicolumn{8}{|c|}{ Jumlah } & 610 \\
\hline \multicolumn{8}{|c|}{ Rata-rata } & 87,1 \\
\hline
\end{tabular}

\section{PEMBAHASAN}

Berdasarkan hasil data awal yang diperoleh siswa tunagrahita sebagian besar menunjukkan sikap sosial yang kurang. Hal ini didasarkan pada nilai yang diperoleh siswa yang mendapatkan skor di bawah 49. Selanjutnya dari hasil observasi awal sikap sosial siswa teridentifikasi siswa masih mementingkan kepentingan pribadi dibandingkan sosial dan masih belum diterima sebagai anggota kelompok sosial. Setelah siswa mengikuti pelatihan membuat karya seni mozaik yang dilaksanakan secara berkelompok, terdapat perbedaan rata-rata skor yang signifikan. Rata-rata skor awal diperoleh 37,1 setelah dilakukan kegiatan membuat karya seni mozaik secara berkelompok menunjukkan ratarata 87,1 . Dari hal ini dapat dilihat adanya peningkatan sikap sosial siswa menjadi lebih baik dibandingkan sebelumnya. Peningkatan sikap sosial siswa tunagrahita dilihat dari tercapainya indikator penilaian yang digunakan dalam melaksanakan observasi mengenai sikap sosial siswa tunagrahita kelas V di SLB Negeri 2 Buleleng. Untuk melihat bukti fisik dari pelaksanaan pelatihan membuat karya seni mozaik dapat dilihat pada laman https://osf.io/nzguf/?view_only=053808c76cd647ddb45e1263ffaa38de.

Indikator pertama mengenai tindakan siswa menanggapi orang lain sudah dicapai dengan baik. Pada awalnya terdapat beberapa siswa yang memiliki sikap yang pendiam, kurang memperhatikan dan menanggapi pertanyaan ataupun pernyataan dari orang lain. Siswa cenderung memiliki sikap tertutup terutama dengan orang yang baru dikenali. Selain itu, dalam pembelajaran siswa cenderung bekerja sendiri dan tidak mau bekerja secara berkelompok. Namun, setelah dilaksanakan pembelajaran membuat karya seni mozaik secara berkelompok, awalnya siswa yang saling diam perlahan sudah mampu 
Heni, Agus, Noviana, Suranata. Pelatihan Membuat Karya Seni....

berinteraksi dan saling menanggapi pertanyaan dan pernyataan dari orang lain terutama dari teman sekelompoknya.

Indikator kedua mengenai sikap siswa mementingkan tujuan-tujuan sosial daripada tujuan pribadi sudah mulai berkembang. Awalnya terdapat beberapa siswa yang memiliki sikap lebih mementingkan tujuan pribadi dibandingkan tujuan sosialnya yang diharapkan. Siswa dalam pembelajaran apabila dikelola secara kelompok, siswa tunagrahita cenderung kurang mampu bekerja sama dengan teman kelompoknya dalam melakukan suatu hal. Siswa terlihat kurang nyaman dan sering memperebutkan sesuatu dengan teman kelompoknya. Namun, dalam pelaksanaan pembuatan karya seni mozaik yang dikelola dengan cara berkelompok, siswa perlahan sudah mau berintekasi dan juga bekerja sama. Siswa saling membantu dalam kegiatan membuat karya seni mozaik seperti membantu memberi lem pada kertas dan menempelkan kertas ke pola yang sudah disediakan.

Indikator ketiga mengenai perilaku sesuai dengan tuntunan sosial. Siswa pada awalnya siswa menunjukkan berperilaku yang kurang sesuai dengan tuntunan sosial yang diharapkan seperti melaksanakan pembelajaran secara berkelompok namun siswa cenderung menolak hal tersebut. Dalam pembelajaran guru kurang memberikan pembelajaran secara berkelompok karena siswa cenderung kurang nyaman bersama teman kelompoknya dan sering berebut apabila diberikan sesuatu yang harus dikerjakan bersama. Namun, setelah dilaksanakannya pelatihan membuat karya seni mozaik, siswa dapat berinteraksi dan juga bekerja sama dengan teman kelompoknya dalam membuat karya seni mozaik. Dalam hal ini terlihat siswa sudah mampu berperilaku dengan baik sesuai dengan tuntunan yang diharapkan terutama dalam kegiatan pembelajaran.

Indikator keempat mengenai diterima sebagai anggota kelompok sosial. Siswa tunagrahita pada awalnya cenderung kurang dapat menerima anggota kelompok terutama dalam kegiatan pembelajaran. Siswa terlihat kurang nyaman apabila pembelajaran dikelola secara berkelompok. Selain itu, adanya satu siswa hiperaktif yang sering bertindak semaunya membuat beberapa teman-teman lain kurang mau menerima dia sebagai anggota kelompok. Namun, dalam kegiatan membuat karya seni mozaik secara berkelompok, siswa menunjukkan sikap yang sangat baik dengan menerima semua teman menjadi anggota kelompoknya. Siswa menunjukkan sikap mau bekerja sama dan berinteraksi dengan baik dalam menyelesaikan karya seni mozaik bersama. 
Heni, Agus, Noviana, Suranata. Pelatihan Membuat Karya Seni....

Selain itu, setelah selesai membuat karya seni mozaik, siswa saling membantu satu sama lain saat mencuci tangan yang sebelumnya berisi lem.

Indikator kelima mengenai menyukai aktivitas sosial. Dalam pelaksanaan membuat karya seni mozaik terlihat siswa sangat menyukai aktivitas sosial terutama siswa mau bekerja sama dengan anggota kelompok, dapat berinteraksi satu sama lain dan menunjukkan sikap baik di dalam kelompok. Dari hal ini, penulis menyatakan bahwa siswa mulai menyukai aktivitas sosial seperti bekerja sama melalui kegiatan membuat karya seni mozaik.

\section{SIMPULAN}

Berdasarkan hasil penelitian dan analisis data, dapat disimpulkan bahwa hasil analisis menunjukkan adanya peningkatan sikap sosisal siswa tunagrahita kelas V SLB Negeri 2 Buleleng. Hal ini dilihat dari rata-rata skor awal yang diperoleh 37,1 dan setelah dilaksanakan pelatihan kegiatan membuat karya seni mozaik secara berkelompok menunjukkan rata-rata 87,1. Dengan demikian, dapat disimpulkan pelatihan membuat karya seni mozaik dapat meningkatkan sikap sosial siswa tunagrahita kelas V SLB Negeri 2 Buleleng.

\section{UCAPAN TERIMA KASIH}

Penulis mengucapkan terima kasih kepada semua pihat yang terlibat dalam penyusunan penelitian ini. Terima kasih penulis ucapkan kepada Jurnal Pendidikan Dasr Nusantara atas izin mengirimkan artikel kami. Ucapan terima kasih juga kami sampaikan kepada Kepala SLB Negeri 2 Buleleng, Wali Kelas V dan siswa kelas V yang menjadi subjek dalam penelitian ini. Serta terima kasih pula kepada Dr. Kadek Suranata, S.Pd., M.Pd., yang menjadi dosen pembimbing dalam penyusunan penelitian ini.

\section{DAFTAR PUSTAKA}

Arikunto, S. 2010. Prosedur Penilaian. Jakarta: Rineka Cipta.

Dwi, G. S. (2018). Penerapan Media Mozaik Dalam Meningkatkan Keterampilan Mengenakan Pakaian Berkancing Pada Anak Tunagrahita Sedang. Doctoral dissertation, Universitas Pendidikan Indonesia.

Juriana, dkk, 2016. Melek ABK. Jakarta: CV. Alumganda Mandiri. 
Heni, Agus, Noviana, Suranata. Pelatihan Membuat Karya Seni....

Lestari, N. D. 2015. Identifikasi sikap sosial siswa kelas V SD. BASIC EDUCATION, Volume 4, Nomor 8.

Yustiana, T. 2018. Pemanfaatan Bahan Alam Biji-Bijian Untuk Meningkatkan Keterampilan Membuat Mozaik Dalam Tema Kegiatanku Di Kelas 1 Sekolah Dasar. Jurnal Penelitian Pendidikan Guru Sekolah Dasar, Volume 6, Nomor 2.

Prasetya, A. N. 2018. Implementasi Sikap Sosial Siswa Pada Pembelajaran Bahasa Indonesia Kelas IIi Di SDN I Kacangan Kecamatan Ngunut Kabupaten Tulungagung. Doctoral Dissertation. Malang: University of Muhammadiyah Malang.

Pratiwi, D. A., \& Kustiawan, U. 2018. Pembelajaran Toilet Training bagi Siswa Tunagrahita. Jurnal ORTOPEDAGOGIA, Volume 3, Nomor 2, Hlm 91-95.

Yusuf, Y. 2017. Peran Guru terhadap Anak Penyandang Tunagrahita Ditinjau dari Kinerja Kompetensi Guru (Studi Kasus Sekolah Luar Biasa Negeri Pembina Pekanbaru). Jurnal Online Mahasiswa (JOM) Bidang Ilmu Sosial dan Ilmu Politik, Volume 4, Nomor 2, Hlm 1-13. 